\title{
Pengaruh Temperatur Permukaan Panel Surya Terhadap Daya Yang Dihasilkan Dari Berbagai Jenis Sel Surya
}

\author{
Partaonan Harahap \\ Program Studi Teknik Elektro, Fakultas Teknik \\ Universitas Muhammadiyah Sumatera Utara (UMSU) \\ Jl. Kapten Muchtar Basri,BA No. 03 Medan Telp. (061) 6622400 ex. 12 Kode pos 20238 \\ e-mail: partaonanharahap@umsu.ac.id
}

\begin{abstract}
Abstrak - Dalam penelitian ini untuk mendapatkan pengaruh temperatur,dan perbandingan 2 merk panel sel surya dilakukan pengukuran berdasarkan intensitas 1225 dan temperatur $41,1^{\circ} \mathrm{C}$. Pengukuran yang dimaksud adalah melihat besarnya tegangan Merk A 20,3 Volt dan B 3,5 volt, arus Merk A 1,17 Amper dan B 1,68 Amper, daya output Merk A 19,21 Watt dan B 16,94 Watt, daya input Merk A 183 Watt dan B 226 Watt antara tiap panel sel surya. Pada pengukuran dua panel surya jenis polycrystalline merk A dan B, dapat disimpulkan bahwa dari kinerja pada panel sel surya dari merek A dan B yang lebih bagus adalah B dikarenakan nilai penyerapan pada B lebih besar dibandingkan dengan surya dikarenakan nilai Imp penyerapan yang berbeda tiap jenis dan tipe. Ada beberapa faktor yang mempengaruhi peningkatan daya yang dihasilkan yaitu temperatut permukaan panel sel surya sangat berpengaruh terhadap efisiensi yang dihasilkan dari panel surya yang artinya semangkin rendah suhu permukaan maka efisiensi Pv akan semangkin meningkat begitupun sebaliknya.
\end{abstract}

Kata kunci : Panel Sel Surya, Temperatur

Abstract - In this study to get the effect of temperature, and the comparison of 2 brands of solar cell panels was measured based on the intensity of 1225 and the temperature of $41.1^{\circ} \mathrm{C}$. The measurement in question is to see the magnitude of Brand A voltage of 20.3 Volts and B 3.5 volts, the current of Brand $A$ 1.17 Amperes and B 1.68 Amperes, the output power of Brand A 19.21 Watts and B 16.94 Watts, the power input Brand A 183 Watt and B 226 Watt between each solar cell panel. In the measurement of two polycrystalline type solar panels brands $A$ and $B$, it can be concluded that the performance of the solar cell panels of brands $A$ and $B$ is better, $B$ because the absorption value in $B$ is greater than that of solar because the Imp absorption value is different for each type and type. There are several factors that influence the increase in power generated, namely the surface temperature of solar cell panels is very influential on the efficiency generated from solar panels, which means that the lower the surface temperature, the efficiency of $P v$ will increase and vice versa.

Keywords : $\quad$ Solar Cell Panel, Temperature

\section{PENDAHULUAN}

Kebutuhan akan sumber energi pada saat ini sangat mendesak dibutuhkan berbagai macam produk yang mendukung kinerja dari manusia saat ini semuanya menggunakan tenaga listrik. Pada saat ini semakin banyak dikembangkan sumber tenaga atau sumber energi alternative. Salah satunya adalah menggunakan tenaga matahari. Pemanfaatan energi matahari digunakan untuk mengkonversikan energi (sel surya) menjadi energi listrik, yang dirancang menjadi panel surya. Panel surya dibangun modulmodul solar sel yang dapat menyerap energi matahari dan merubahnya menjadi sumber listrik atau energi yang dapat digunakan dalam kehidupan sehari-hari (Martawi,2018).

Salah satu pemanfaatan energi cahaya matahari adalah Pembangkit Listrik Tenaga Surya yang memanfaatkan energi foton cahaya matahari menjadi energi listrik. Indonesia sendiri, sebuah negara yang dilewati oleh garis khatulistiwa dan menerima panas matahari yang lebih banyak dari pada negara lain, mempunyai potensi yang sangat besar untuk mengembangkan pembangkit listrik tenaga surya sebagai alternatif batubara dan diesel sebagai pengganti bahan bakar fosil, yang bersih, tidak berpolusi, aman dan persediaannya tidak terbatas (Rotib, 2001).

Kenapa saya memilih judul pengaruh intensitas dan temperatur permukaan penel surya pada berbagai jenis sel surya karena dengan adanya jenis dan merk pada panel sel surya yang ada dipasaran, agar kita tau memilih panel sel surya yang baik dan benar, dengan biaya terjangkau dan kualtitas bagus, maka dari itu penulis tertarik.

\section{TINJAUAN PUSTAKA}

Pembangkit listrik tenaga suryaPLTS adalah pembangkit listrik yang mengubah energi surya/energi matahari menjadi energi listrik. Cahaya matahari merupakan salah satu bentuk energi dari sumber daya alam. Sumber daya alam matahri ini 
sudah banyak digunakan untuk memasok daya listrik di satelit komunikasi melalui sel surya. Sel surya ini dapat menghasilkan energi listrik dalam jumlah yang tidak terbatas langsung diambil dari matahari, tanpa ada bagian yang berputar dan tidak memerlukan bahan bakar. Sehingga sistem sel surya sering dikatakan bersih dan ramah lingkungan. PLTS terdiri dari komponen-komponen sebagai berikut:

Modul Surya, yang berfungsi untuk mengubah energi matahari menjadi energi listrik arus searah, baterai, yang berfungsi untuk menyimpan energi listrik yang dihasilkan oleh modul surya, Solar Charge Controller, yang berfungsi untuk mengatur pengisian baterai, inverter, yang berfungsi untuk mengubah listrik arus searah menjadi arus bolak-balik (Saputro \& Yandri \& Khwee, 2017).

\section{Panel Surya}

Panel surya terdiri dari beberapa sel surya yang di susun sedemikian rupa sehingga didapatkan output sesui dengan yang diinginkan. Dari kumpulan sel surya ini dapat dikonversi cahaya matahari menjadi listrik arus searah. Dengan menambahkan baterai yang dihubungkan dengan panel surya, maka daya hasil konversi cahaya matahari menjadi listrik dapat disimpan sebagai cadangan energi listrik. Secara sederhana sel surya terdiri dari persambungan bahan semikonduktor bertipe $\mathrm{P}$ dan $\mathrm{N} P-N$ junction semiconductor yang jika terkena sinar matahari maka akan terjadi aliran elektron, aliran elektron inilah yang disebut sebagai aliran arus listrik. Proses pengubahan energi matahari menjadi energi listrik ditunjukan dalam Gambar 1 di bawah ini :

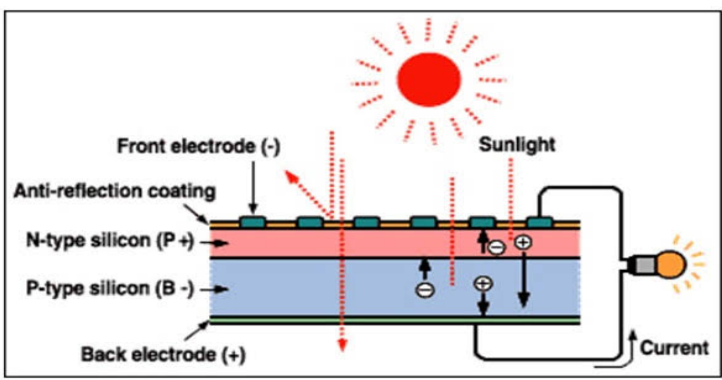

Gambar 1. Proses Pengubahan Energi Matahari menjadi Energi Listrik pada Sel Surya

Hole secara kontinyu meninggalkan tipe-p dan menyebabkan ion negatif akseptor tertinggal di dekat sambungan. Begitupun dengan elektron yang meninggalkan tipe-n akan menyebabkan beberapa ion positif donor tertinggal didekat sambungan Gambar 1. Sebagai konsekuensinya, ruang muatan negatif terbentuk di daerah tipe-p dan ruang muatan positip terbentuk di daerah tipe-n dekat sambungan, sampai tepat pada sambungan $\mathrm{p}-\mathrm{n}$ terjadi daerah tanpa muatan bebas yang disebut daerah pengosongan depletion region (Shodiq, 2017).

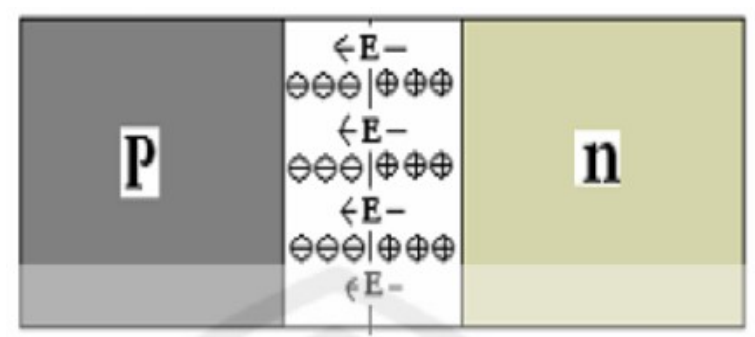

Gambar 2. Medan listrik di daerah pengosongan beratah dari kanan ke kiri

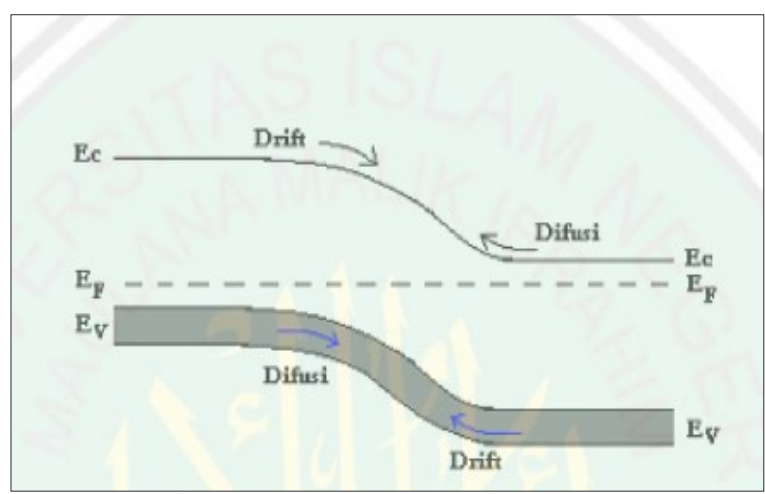

Gambar 3. Arah gerak difusi elektron-hole: difusi dari pembawa muatan mayoritas dan drift dari pembawa muatan minoritas

Panel surya merupakan sel Fotovolteik yang merupah perangkat listrik yang merubah energi dari cahaya matahari langsung dari cahaya matari langsung menjadi listrik oleh efek fotovolteik.
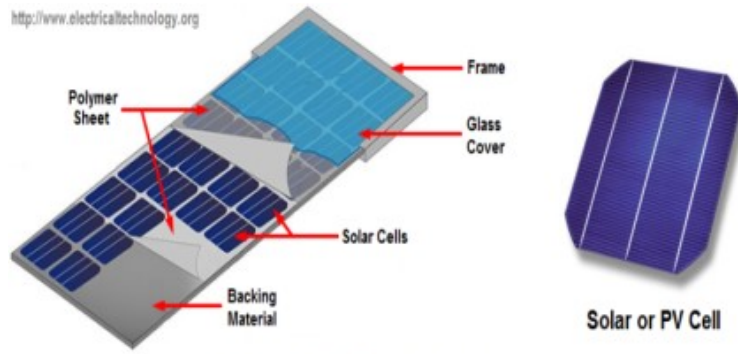

\section{Solar Cell Construction}

Gambar 4. Modul Panel Surya

Temperatur sel surya, $\mathrm{T}_{\mathrm{c}}$ adalah temperatur yang diukur pada permukaan panel surya. Pada malam hari, nilai temperatur ini sama dengan temperatur lingkungan ekitarnya, namun pada siang hari saat terik matahari, nilai temperatur ini dapat mencapai $30^{\circ} \mathrm{C}$ atau lebih diatas temperatur lingkungan sekitarnya (Heikwee, 2013).

Untuk menghitung temperatur sel surya ini dapat menggunakan persamaan sebagai berikut: 


$$
T_{c}=T_{a}+I_{r}\left(\frac{T c, N O C T-T a, N O C T}{I T, N O C T}\right)\left(1-\frac{n c}{T a}\right)
$$

di mana $T_{a}$ adalah temperatur daerah sekitar $\left({ }^{\circ} \mathrm{C}\right)$, $T_{c, N O C T}$ adalah temperatur daerah sekitar di mana temperatur nominal sel surya di definisikan $\left(20^{\circ} \mathrm{C}\right)$, $I_{T}$, NOCT adalah radiasi matahri pada temperatur nominal sel surya didefinisikan $\left(0,8 \mathrm{~kW} / \mathrm{m}^{2}\right)$, $\gamma_{\mathrm{c}}$ adalah efisiensi konversi listrik panel surya $(\%)$, serta tingkat penyerapan panel surya.

\section{Macam-macam Bahan Pembuatan Sel Surya}

Bahan yang digunakan banyak jenisnya dan memiliki efisiensi yang berbeda-beda. Macammacam bahan pembuatan sel surya adalah sebagai berikut (Ernaning,2004):

\section{Poly-crystalline}

Dibuat dari peleburan silikon dalam tungku keramik, kemudian pemdinginan perlahan untuk mendapatkan bahan campuran silikon yang akan timbul di atas lapisan silikon. Sel ini kurang efektif dibandingkan dengan sel momo-crystalline (efektifitas 18\%), tetapi biaya lebih murah(Ernaning,2004).

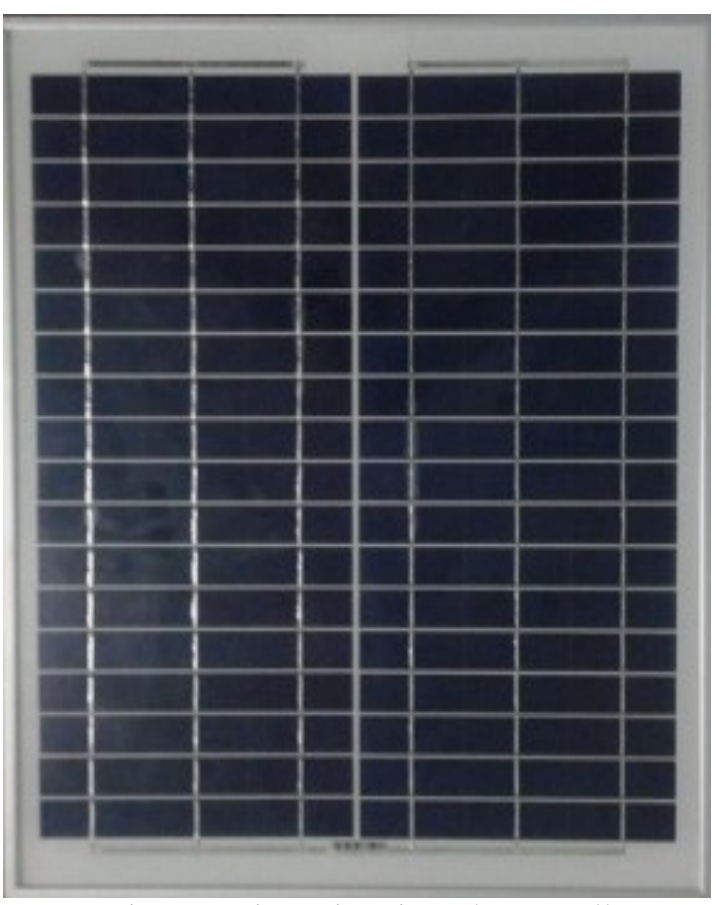

Gambar 5. Soler Sel Jenis Poly-crystalline

\section{Mono-crystalline}

Dibuat dari silikon kristal tunggal yang didapat dari peleburan silikon dalam bentuk bujur. Mono-crystalline dapat dibuat setelah 200 mikron,dengan nilai efisiensi sekitar $24 \%$.

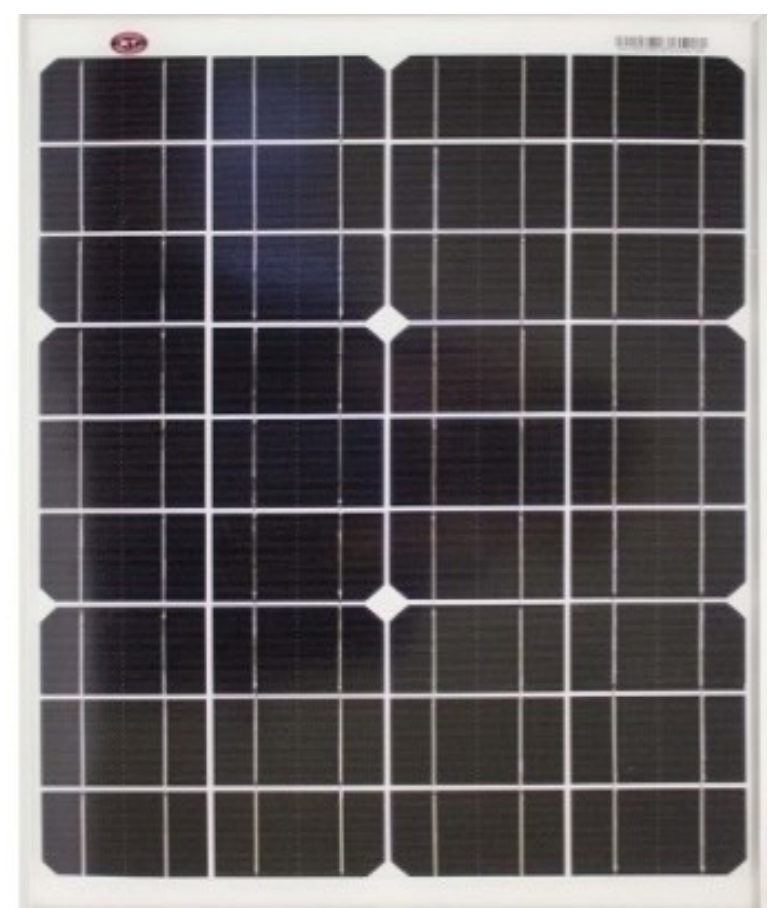

Gambar 6. Solar Sel Jenis Mono-crystalline. Gallium Asenide

Sel surya III-IV semikonduktor yang sangat efisiensi sekitar $25 \%$ sel surya silikon terpadu " Thin Film".

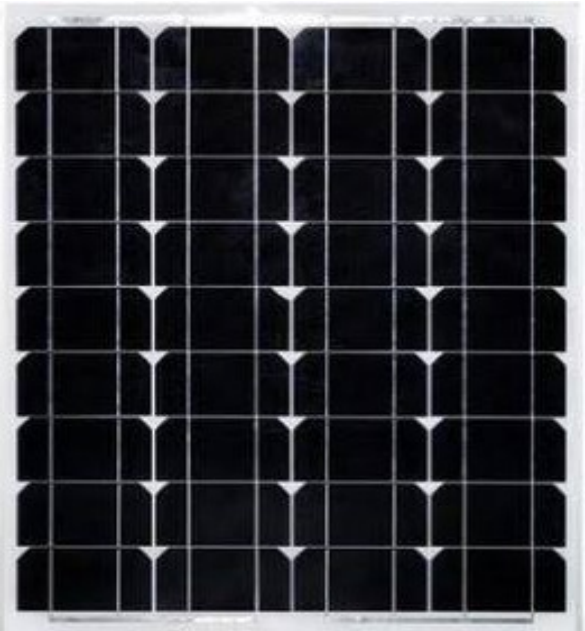

Gambar 7. Solar Sel Jenis Gallium Asenide

a. Amorphous Silikon

Sebagai pengganti tinted glass yang semi transparan

b. Thin Film Silikon

Dibuat dari thin-crystalline atau polycrystallinepada bahan metal yang cukup murah (cladding system)

c. Cadmium Telluride

Terbentuk dari bahan material thin film polycrystalline secara deposit, semprot dan evaporasi tingkat tinggi. Nilai efisiensi $16 \%$. 
3. Copper Indium Diselenide

Merupakan bahan dari film tipis poly-crystalline. Nilai efisiensi $17.7 \%$.

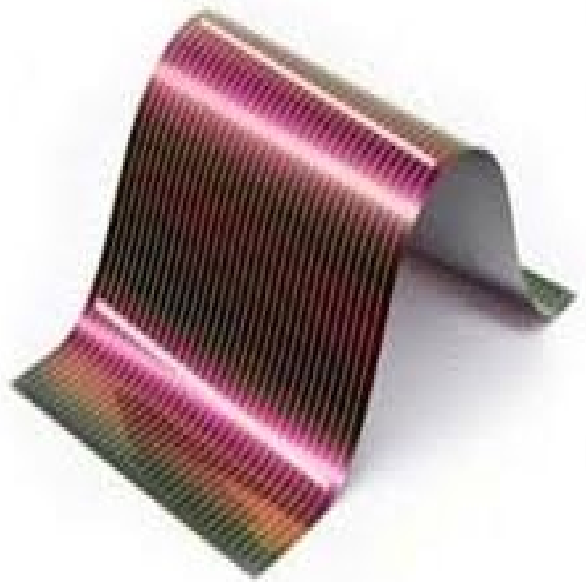

Gambar 8. Solar Sel Jenis Copper Indium Diselenide (Ernaning,2004)

\section{METODE}

Penelitian dan pengujian panel sel surya berdasarkan intensitas dan temperatur permukaan panel surya pada berbagai jenis sel surya. dilaksanakan laboratorium Universitas Muhammadiya Sumatera Utara, jalan. Kapten Muchtar Basri No. 3 Medan. Peralatan dan bahan yang digunakan dalam penelitian diantaranya sebagai berikut:

1. Thermometer

2. Lux meter

3. Multitester

4. Kabel penghubung

5. Solar charger controller

6. Inverter 500 watt DC $12 \mathrm{v}$ AC $220 \mathrm{v}$

7. Batrai

Bahan utama yang digunakan dalam penelitian 2 buah panel sel surya diantaranya sebagai berikut.

1. Panel sel surya $20 \mathrm{Wp}$ jenis polycrystalline A

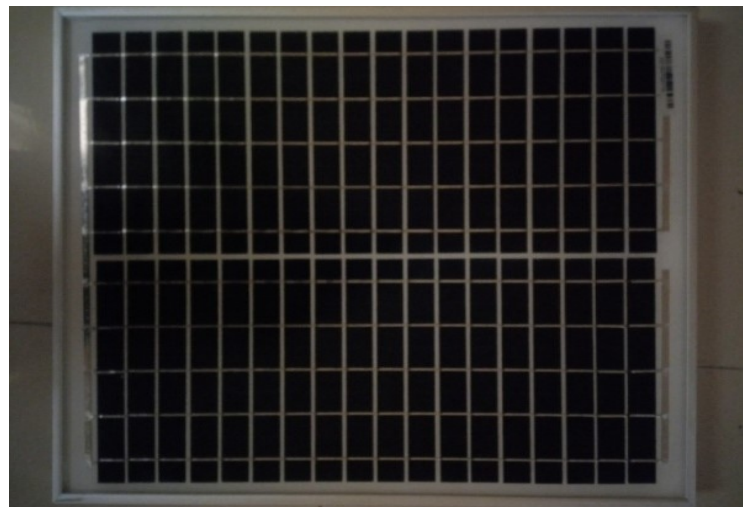

Gambar 9. Panel Surya Merek A Jenis Polycrystallin
Tabel 1.Spesifikasi panel surya A

\begin{tabular}{|c|c|c|}
\hline \multicolumn{3}{|c|}{ POLYCRYSTALLINE SOLAR MODULE } \\
\hline Model Type & SSPP 2 & $\mathrm{WP} / 12 \mathrm{~V}$ \\
\hline $\begin{array}{l}\text { Rated Maximum } \\
\text { Power: }\end{array}$ & {$[\operatorname{Pmax}]$} & $20 \mathrm{~W}$ \\
\hline $\begin{array}{c}\text { Output } \\
\text { Tolerrance: }\end{array}$ & \multicolumn{2}{|c|}{$0 \sim+3 \%$} \\
\hline Voltage at Pmp: & {$[\mathrm{Vmp}]$} & $18 \mathrm{~V}$ \\
\hline Current at Pmp: & [Imp] & $1.11 \mathrm{~A}$ \\
\hline $\begin{array}{l}\text { Open-Circuit } \\
\text { Voltage: }\end{array}$ & [Voc] & $21.5 \mathrm{~V}$ \\
\hline $\begin{array}{l}\text { Short-Circuit } \\
\text { Current: }\end{array}$ & [Isc] & $1.23 \mathrm{~A}$ \\
\hline $\begin{array}{c}\text { Maximum } \\
\text { System Voltage: }\end{array}$ & \multicolumn{2}{|c|}{$1000 \mathrm{~V}$} \\
\hline $\begin{array}{l}\text { Maximum Series } \\
\text { Fuse Rating: }\end{array}$ & \multicolumn{2}{|c|}{$15.0 \mathrm{~A}$} \\
\hline Weight: & {$[\mathrm{Kg}]$} & 2.0 \\
\hline Dimension: & {$[\mathrm{mm}]$} & $485 * 350 * 25 \mathrm{~mm}$ \\
\hline $\begin{array}{l}\text { Application } \\
\text { Class }\end{array}$ & \multicolumn{2}{|r|}{ A } \\
\hline \multicolumn{3}{|c|}{ ALL Technical data at standard condition } \\
\hline $\mathrm{AM}=1.5$ & $\mathrm{E}=1000 \mathrm{~W} / \mathrm{M}^{2}$ & $\mathrm{TC}=25^{\circ} \mathrm{C}$ \\
\hline $07 / 2018$ & \multicolumn{2}{|c|}{ MADE IN CHINA } \\
\hline
\end{tabular}

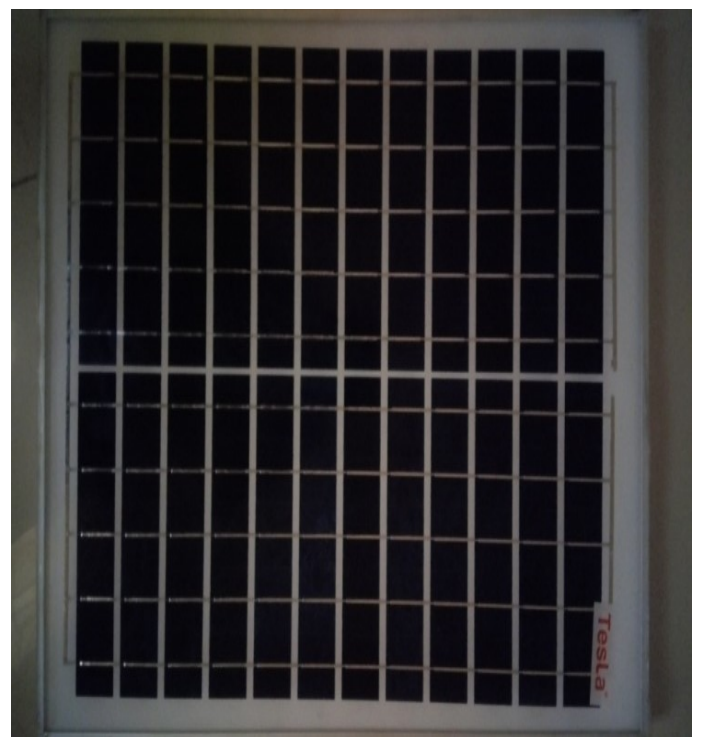

Gambar 10. Panel Surya Merek B jenis Polycrystalline

Tabel 2.Spesifikasi panel B

\begin{tabular}{|c|c|c|}
\hline MEREK B $^{\circledR}$ & POLYCRYSTALLINE-20W \\
\hline Rated Power & Pmax & $20 \mathrm{~W}$ \\
\hline Rated Voltage & Vpm & $12 \mathrm{~V}$ \\
\hline Rated Current & Ipm & $1.6 \mathrm{~A}$ \\
\hline $\begin{array}{c}\text { Open Circuit } \\
\text { Voltage }\end{array}$ & Voc & $14.4 \mathrm{~V}$ \\
\hline $\begin{array}{c}\text { Short Circuit } \\
\text { Voltage }\end{array}$ & Isc & $1.76 \mathrm{~A}$ \\
\hline \multicolumn{2}{|c|}{ Modul ini telah sesuai dengan IEC 61215 dan } \\
IEC61730 \\
\hline
\end{tabular}


Urutan penelitian dan analisa data dituangkan dalam alur diagram seperti 3.1 yakni penelitian diawali dari waktui dan tempat,3.1 peralatan dan bahan panel surya 1,2 , pada saat di pasang dapat kita ketahui bahwa perbandingan jenis dan merek panel sel surya 1, 2, pada intensitas dan temperatur dari panel sel surya tersebut. Sehingga kita dapat mengetahui karakter tiap jenis dan merek panel sel surya yang beredar dipasaran.

Pengujian sendiri dilakukan dengan mengamati tegangan (voult), arus (ampera) dan daya output (Watt). Kemudian dapat diketahui juga intensitas dan temperatur permukaan panel surya yang telah di ukur menggunakan luxmeter dan thermometer. Setelah semua data terkumpul dan dirasa cukup, penelitian mulai menyusun laporan penelitian.

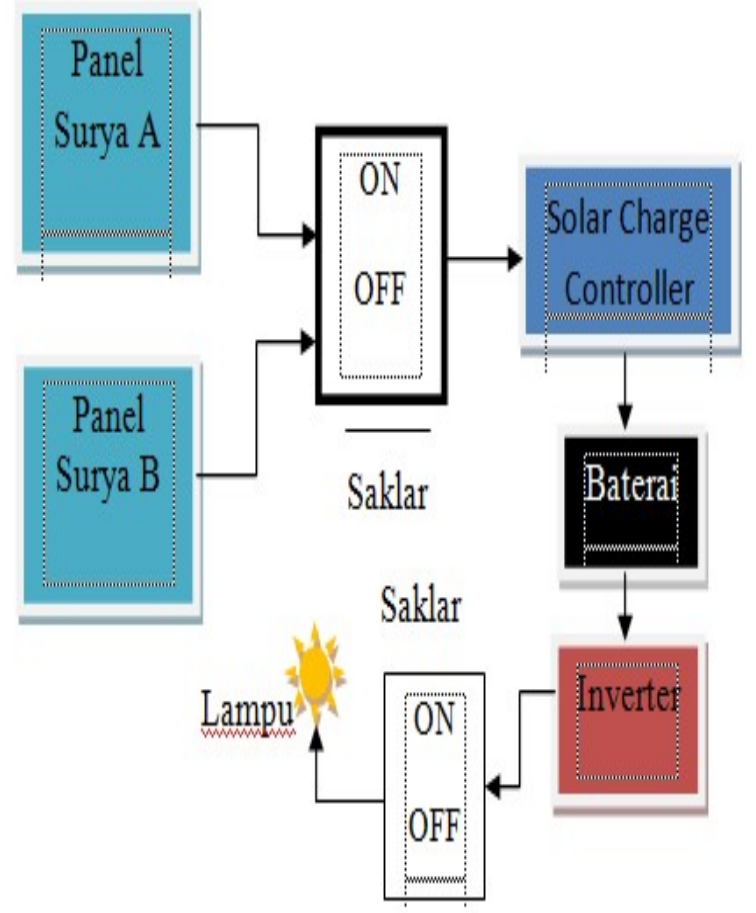

Gambar 11. Diagram Blok Pengukuran 2 Panel surya

\section{HASIL DAN PEMBAHASAN}

Penelitian yang dilakukan untuk mengetahui perbandingan besarnya tegangan, arus dan daya yang dihasilkan oleh panel surya dengan perbedaan intensitas dan temperatur dari matahari. Pada pengujian tenaga surya ini, terdiri dari beberapa komponen, seperti: panel surya (PV),Luxmeter, Thermometer, Multitester selanjutnya dari arus dan tegangan yang dihasilkan di ukur dengan alat tersebut. Pengujian ini bertujuan untuk membandingkan 2 buah panel sel surya yang beredar dipasaran, dengan di adakannya pengujian maka pembeli dapat lebih teliti lagi dalam menentukan pilihan pada jenis dan merek panel sel surya yang akan dibeli.

\section{Hasil Penelitian}

Pengujian dilakukan dalam waktu satu hari dan dilakukan pengambilan data setiap tiga jam sekali. Pengujian ini menggunakan sistem rotasi dinamis dengan cara manual untuk menggerakan sel surya menghadap kearah datangnya cahaya matahari dari timur ke barat. Dengan cara menggunakan rotasi dinamis di harapkan akan dapat meningkatkan daya output yang dihasilkan sel surya. Penelitian menggunakan 2 buah panel surya dengan ke mampuan masing-masing panel 20Wp. Panel surya dipasang pada tempat yang terpapar sinar matahari secara langsung.

2. Pengujian Pertama Pengukuran Arus, Tegangan Dan Daya Output, Input Pada Panel Sel Surya Jenis Polycrystalline Merk A

Pengujian terhadap panel surya jenis Polycrystalline dengan merk A dilakukan dalam setiap tiga jam sekali.

Tabel 3. Data Hasil Pengujian Panel Sel Surya Jenis Polycrystalline Merk A

\begin{tabular}{|c|c|c|c|c|c|c|}
\hline $\begin{array}{c}\text { Waktu } \\
\text { Uji }\end{array}$ & $\begin{array}{c}\text { Kondisi } \\
\text { Cuaca }\end{array}$ & $\begin{array}{c}\text { Intensitas } \\
\text { (Lux) }\end{array}$ & Temperatur & Sudut & $\begin{array}{c}\text { Arus } \\
(\mathrm{A})\end{array}$ & $\begin{array}{c}\text { Tegangan } \\
(\mathrm{V})\end{array}$ \\
\hline $09: 00$ & Cerah & 1225 & $41,1^{\circ} \mathrm{C}$ & $\angle 40^{\circ}$ & 1,17 & 20,3 \\
\hline $12: 00$ & Berawan & 444 & $35,9^{\circ} \mathrm{C}$ & $\angle 90^{\circ}$ & 1,24 & 20,1 \\
\hline $15: 00$ & Cerah & 1110 & $36,6^{\circ} \mathrm{C}$ & $\angle 110^{\circ}$ & 1,06 & 20,8 \\
\hline $18: 00$ & Berawan & 930 & $36,4^{\circ} \mathrm{C}$ & $\angle 140^{\circ}$ & 1,63 & 20,6 \\
\hline
\end{tabular}

Pengujian panel surya kedua, pengujian dilakukan dalam waktu atau jam yang bersamaan Hasil pengujian kedua ditunjukan pada tabel 4 . berikut.

3. Pengujian Kedua Pengukuran Arus, Tegangan Dan Daya Output, Input Pada Panel Surya Merk B

Pengujian terhadap panel surya jenis Polycrystalline dengan merk B dilakukan dalam setiap tiga jam sekali.

Tabel 4. Data Hasil Pengujian Panel Sel Surya Jenis Polycrystalline Merk B

\begin{tabular}{|c|c|c|c|c|c|c|}
\hline Waktu Uji & $\begin{array}{c}\text { Kondisi } \\
\text { Cuaca }\end{array}$ & $\begin{array}{c}\text { Intensitas } \\
\text { (Lux) }\end{array}$ & Temperatur & Sudut & $\begin{array}{c}\text { Arus } \\
(\mathrm{A})\end{array}$ & $\begin{array}{c}\text { Tegangan } \\
\text { (V) }\end{array}$ \\
\hline $09: 00$ & Cerah & 1225 & $41,1^{\circ} \mathrm{C}$ & $\angle 40^{\circ}$ & 1,68 & 13,5 \\
\hline $12: 00$ & Berawan & 444 & $35,9^{\circ} \mathrm{C}$ & $\angle 90^{\circ}$ & 1,08 & 13,8 \\
\hline $15: 00$ & Cerah & 1110 & $36,6^{\circ} \mathrm{C}$ & $\angle 110^{\circ}$ & 1,66 & 15,26 \\
\hline $18: 00$ & Berawan & 930 & $36,4^{\circ} \mathrm{C}$ & $\angle 140^{\circ}$ & 1,21 & 15,65 \\
\hline
\end{tabular}


4. Perbandingan Tegangan, Arus Daya Output, Input Panel Surya A Surya Dan B.

Dari hasil analisa dan pengujian yang dilakukan , maka dapat ditentukan perbandingan tegangan antara dua merk panel surya melalui gambar grafik di bawah.

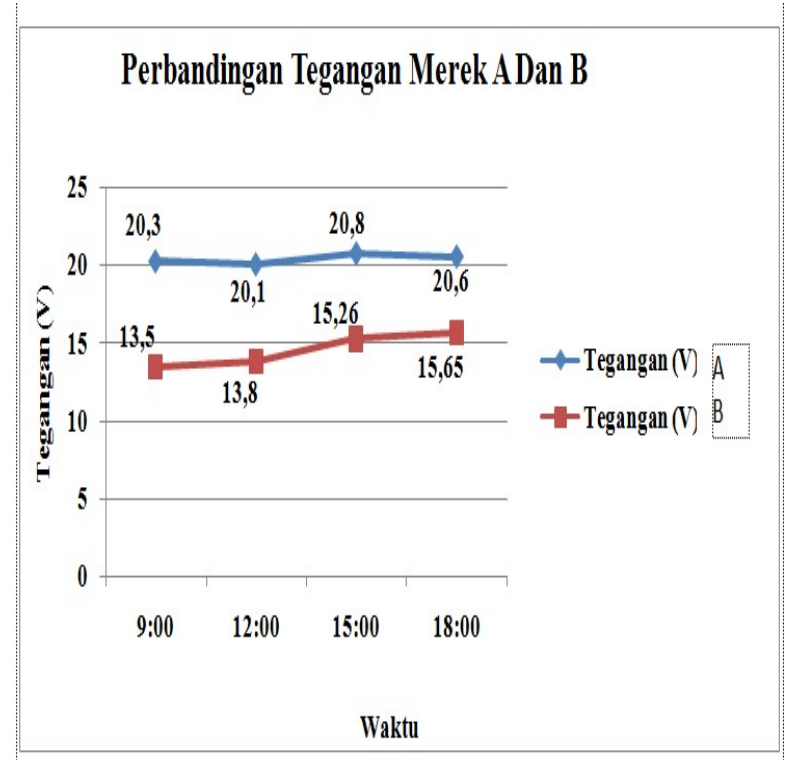

Gambar 12. Grafik Perbandingan Tegangan Panel Sel Surya Merek A Dan B

Dari hasil analisa dan pengujian yang dilakukan, maka dapat ditentukan perbandingan arus antara dua merk panel surya melalui gambar grafik di bawah.

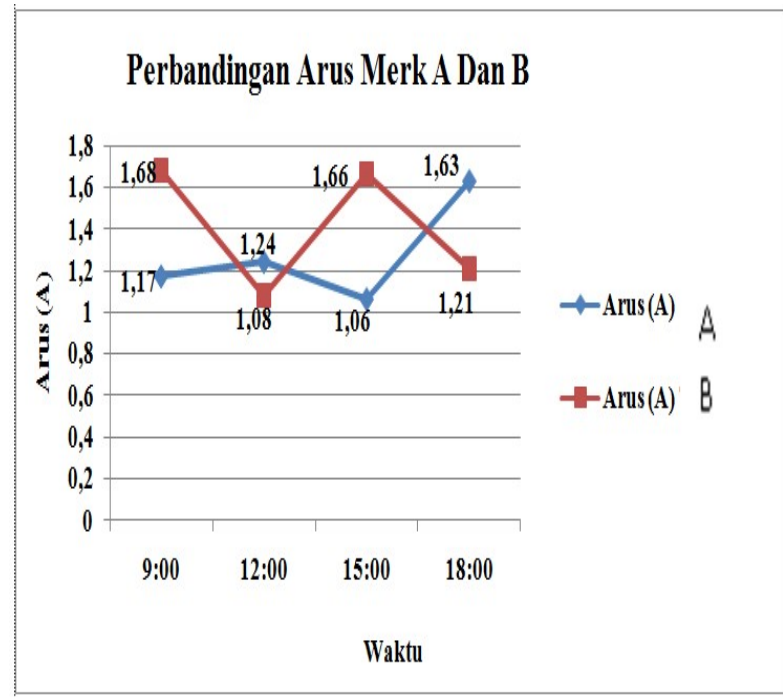

Gambar 13. Grafik Perbandingan Arus Merek

\section{A Dan B}

Selanjutnya, dari perhitungan daya yang dihasilkan tiap panel sel surya jenis polycrystalline merk A dan B hasil ditunjukkan pada gambar tabel dibawah
Tabel: 5. Hasil Daya Outputdan Input Modul Panel Surya Merk A

\begin{tabular}{|c|c|c|c|c|c|c|c|c|c|}
\hline $\begin{array}{c}\text { Waktu } \\
\text { Uji }\end{array}$ & $\begin{array}{c}\text { Kondisi } \\
\text { Cuaca }\end{array}$ & $\begin{array}{c}\text { Intensitas } \\
(\text { Lux })\end{array}$ & Temperatur & Sudut & $\begin{array}{c}\text { Tegangan } \\
\text { ( ) }\end{array}$ & $\begin{array}{c}\text { Arus } \\
(\mathrm{A})\end{array}$ & $\begin{array}{c}\text { Daya } \\
\text { Output } \\
\text { (W) }\end{array}$ & $\begin{array}{c}\text { Daya } \\
\text { Input } \\
\text { (V) }\end{array}$ & $\begin{array}{c}\text { Efisiensi } \\
\%\end{array}$ \\
\hline $09: 00$ & Cerah & 1225 & $41,1^{\circ} \mathrm{C}$ & $\angle 40^{\circ}$ & 20,3 & 1,17 & 19,21 & 183 & 10,49 \\
\hline $12: 00$ & Berawan & 444 & $35,9^{\circ} \mathrm{C}$ & $\angle 90^{\circ}$ & 20,1 & 1,24 & 20,13 & 66,6 & 30,22 \\
\hline $15: 00$ & Cerah & 1110 & $36,5^{\circ} \mathrm{C}$ & $\angle 110^{\circ}$ & 20,8 & 1,06 & 17,92 & 166 & 10,79 \\
\hline $18 ; 00$ & Berawan & 930 & $36,4^{\circ} \mathrm{C}$ & $\angle 140^{\circ}$ & 20,6 & 1,63 & 27,26 & 139 & 19,6 \\
\hline
\end{tabular}

Tabel: 6 Hasil Daya Outputdan Input Modul Panel Surya Merk B

\begin{tabular}{|c|c|c|c|c|c|c|c|c|c|}
\hline $\begin{array}{c}\text { Waktu } \\
\text { Uji }\end{array}$ & $\begin{array}{c}\text { Kondisi } \\
\text { Cuaca }\end{array}$ & $\begin{array}{c}\text { Intensitas } \\
\text { (Lux) }\end{array}$ & Suhu & Sudut & $\begin{array}{c}\text { Tegangan } \\
\text { (V) }\end{array}$ & $\begin{array}{c}\text { Arus } \\
\text { (A) }\end{array}$ & $\begin{array}{c}\text { Daya } \\
\text { Output } \\
\text { (W) }\end{array}$ & $\begin{array}{c}\text { Daya } \\
\text { Inut } \\
\text { (W) }\end{array}$ & $\begin{array}{c}\text { Efisiensi } \\
\%\end{array}$ \\
\hline $09: 00$ & Cerah & 1225 & $41,1^{\circ} \mathrm{C}$ & $\angle 40^{\circ}$ & 13,5 & 1,68 & 16,94 & 226 & 7,49 \\
\hline $12: 00$ & Berawan & 444 & $35,9^{\circ} \mathrm{C}$ & $\angle 90^{\circ}$ & 13,8 & 1,08 & 11,19 & 82,14 & 13,62 \\
\hline $15: 00$ & Cerah & 1110 & $36,5^{\circ} \mathrm{C}$ & $\angle 110^{\circ}$ & 15,26 & 1,66 & 19,42 & 205 & 9,47 \\
\hline $18 ; 00$ & Berawan & 930 & $36,4^{\circ} \mathrm{C}$ & $\angle 140^{\circ}$ & 15,65 & 1,21 & 14,60 & 172 & 8,48 \\
\hline
\end{tabular}

Untuk mengetahui perbandingan keluaran daya output dan input pada satu jenis dua merk sel surya tersebut, maka dapat dilihat pada gambar grafik dibawah ini.

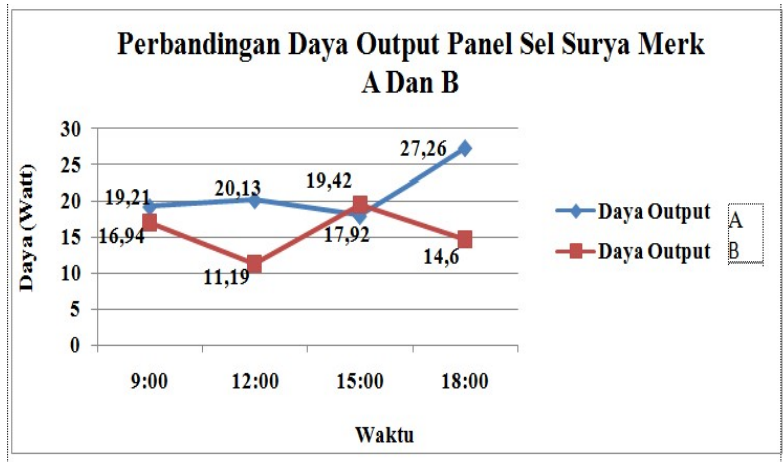

Gambar 14. Grafik Perbandingan Daya Output Dan Input Panel Sel Surya Merk A Dan B

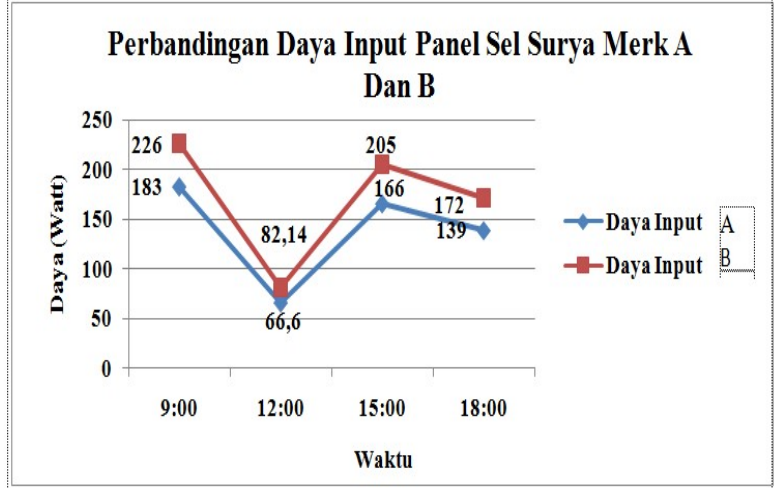

Gambar 15. Grafik Perbandingan Daya Input Panel Sel Surya Merk A Dan B 
5. Pengaruh Intensitas dan Temperatur Terhadap Tegangan, Arus Dan Daya Output, Input Tiap Panel Sel Surya

Pada pengujian panel sel surya merk A dan Bdapat diketahui pengaruh intensitas dan temperatur terhadap tegangan, arus dan daya output, input maka dapat dilihat pada gambar grafik dibawah ini.

Terlihat dari gambar grafik diatassaat intensitas cahaya bernilai $12251 \mathrm{ux}$ dan temperatur bernilai $41,1^{\circ} \mathrm{C}$ panel sel surya merk A mampu menghasilkan daya output 19,21 Watt, input 183 wattdan panel sel surya merk B mampu menghasilkandaya output 16,94 watt, input 226 watt dan saat intensitas terendah 444 lux dan temperatur $35,9^{\circ} \mathrm{C}$ panel sel surya merk A mampu menghasilkan daya output 20,13 watt, input 66,6 watt dan panel sel surya merk B mampu menghasilkan daya output 11,19 watt, input 82,14 watt.

Saat pengukuran intensitas cahaya mencapai 1110 lux dan temperatur $36,5^{\circ} \mathrm{C}$ panel sel surya merk A mampu menghasilkan daya output 17,92 watt, input 166 watt dan panel sel surya merk B mampu menghasilkan daya output 19,42 watt, input 205 watt dan ketika intensitas mencapai 930 dan temperatur $36,4^{\circ} \mathrm{C}$ daya output yang dihasilkan panel sel surya merk A adalah 27,26 watt, input 139 watt dan daya output panel sel surya merk A adalah 14,6 watt, input 172 watt. Jadi terlihat dari grafik saat intensitas dan temperatur paling rendah ataupun paling tinggi panel sel surya merk A menghasilkan daya yang besar, sedangkan panel sel surya merk B menghasilkan daya yang kecil.Tetapi dapat dilihat dari sistem kinerja ke dua panel selAtersebut, panel sel surya merk Byang bagus.

\section{KESIMPULAN}

Berdasarkan penelitian yang dilakukan bahwa ditarik beberapa kesimpulan bahwa Semakin besar intensitas lux maka kinerja panel sel surya semangkin meningkat. Ada beberapa faktor yang mempengaruhi peningkatan daya yang dihasilkan yaitu temperatut permukaan panel sel surya sangat berpengaruh terhadap efisiensi yang dihasilkan dari panel surya yang artinya semangkin rendah suhu permukaan maka efisiensi PV akan semangkin meningkat begitupun sebaliknya. Pada pengukuran dua panel surya jenis polycrystalline merk A dan B dapat disimpulkan bahwa dari kinerja pada panel sel surya merek A dan B yang lebih bagus adalah B dikarenakan nilai penyerapan pada $B$ lebih besar dibandingkan dengan surya dikarenakan nilai Imp penyerapan yang berbeda tiap jenis dan tipe.

\section{DAFTAR PUSTAKA}

[1] Aditiyan., N .2015. Karakterisasi Panel Surya Model SR-156P-100 Berdasarkan Intensitas Cahaya Matahari. Skripsi. Fakultas Teknik Universitas Lampung, Universitas Lampung Bandar Lampung.

[2] B. A. B. Vii and K. Dasar "Inverter 2010" D., Suryana., Mahendra, M, A. 2016. Pengaruh Temperatur / Suhu Terhadap Tegangan Yang Dihasilkan Panel Surya Jenis Monockrystalline, Jurnal Teknologi Proses Dan Inovasi Industri,Baristand Industri Surabaya, 2 (1): halaman 49-52

[3] Ja'far Shodiq, 2017. Simulasi Perporma Photovoltaics Berbahan Nanokristalline $\mathrm{SnO}_{2}$, Jurusan Fisika Fakultas Sains dan Teknologi Universitas Islam Negeri Maulana Malik Ibrahim Malang

[4] Kho Hei Kwee, 2013. Pengaruh Temperatur Kapasitas Daya Panel Surya (Studi Kasus: Pontianak), Universitas Tanjungpura jurusan teknik elektro. Jurnal ELKHA Vol.5, No 2, Oktober 2013

[5] Mira Martawi, Analisa Pengaruh Intensitas Cahaya Jurnal ELTEK, Vol 16Nomor01, April 2018ISS 1693-4024

[6] Noorly Evalina, Rimbawati Rimbawati, Nur Ardiansyah, Seminar Nasional Teknik (SEMNASTEK) UISU Perancangan Sistem Pengontrolan Tegangan Pada Pltb Menggunakan Potensio Dc

[7] Pahlevi, Reza. 2014. Pengujian Karekteristik Panel Surya Berdasarkan Intensitas Tenaga Surya. Surakarta: Universitas Muhammadiyah Surakarta. Halm 11-12

[8] Rimbawat,Ivandar Tambunan, Dadan Ramdan, Journal of Electrical And System Control Engineering Studi Analisis Pemanfatan Transistor 2n3055 Menjadi Solarcell Sebagai Alternatif Pengecasan Handphone

[9] Rotib, Widy, 2001. Aplikasi Sel Surya Sebagai Sumbar Enegi Alternatif ; 
Dimensi Vol 4 No. 1 Juni 2001, Institute for Science and Technology Studies (ISTECS), Jepang. Diakes 20 Februari 2012 . htt://istecs.org/Publication/Dimensi/di m_vol4no1_juni2001.pdf

[10]Sitiyowati, Ernaning.3206 $204 \quad 001$ Teknologi Photovoltaic adalah Salah Satu Strategi Menciptakan Green Architecture. Malang: Universitas Islam Negeri Maulana Malik Ibrahim Malang. Hlm 4

[11] Setiono, Joko, dan Sunaryo, 2014. Analisis Daya Listrik yang Dihasilkan PanelSurya Ukuran $216 \mathrm{~cm} \quad x \quad 121$ cmBerdasarkan Intensitas Cahaya. Pekanbaru: Universitas Muhammadiyah Riau. Hlm 30-32

[12]Saldi Eko Dwi Saputro, Yandri, ST, MT, Ir. 2017 Kho Hei Khwee, Mt. Analisis Perencanaan Pembangkit Listrik Tenaga Surya Berbantuan Program System Sizing Estimator. Jurusan Teknik Elektro, Universitas Tanjungpura

[13] Sungkar, R., 2007, Enegi Surya. Diakses 20 Februari 2012.
[14]Subandi \& Slamet Hani 2014. Korelasi Suhu Dan Intensitas Cahaya TerhadapDaya Pada Solar sel.Jurusan Teknik Elektro Institud Sains \& Teknologo AKPRIND yogyakarta, 15 Novenber 2014

[15] Wibowo, Arymukti, Hadi Nasbey dan Satwiko Sidopekso. 2011. Pengukuran I-V denganMenggunakan Sun Simulator Sederhana.Jakarta: Universitas Negeri Jakarta. Hlm 80

[16] Yuwono, Budi. 2005. Optimalisasi Panel Sel Surya dengan Menggunakan Sistem pelacak Berbasis Mikrokontroler At89c51. Surakarta: Universitas Sebelas Maret. Hlm 69Zian Iqtimal, Ira Devi Sara, Syahrizal., 2018. Aplikasi Sistem Tenaga Surya Sebagai Sumber Tenaga Listrik Pompa Air, Jurusan Tenknik Elektro, Fakultas Teknik. Universitas Syiah Kuala Banda Aceh.

[17] Jauhari., Z. 2018. Pengujian Arus Dan Tegangan Keluaran Pada Pembangkit Listrik Tenaga Surya Dengan Menggunakan Sisitem Rotasi Dinamis. Fakultas Teknik Elektro. Universitas Muhammadiya Sumatra Utara. 